\title{
I got rhythm
}

\author{
Alden H. Harken, MD, FACS
}

From the Department of Surgery, University of California, San Francisco-East Bay, Oakland, Calif

Disclosures: Author has nothing to disclose with regard to commercial support.

Received for publication Aug 2, 2018; accepted for publication Aug 5, 2018; available ahead of print Aug 31, 2018.

Address for reprints: Alden H. Harken, MD, FACS, Department of Surgery, University of California, San

Francisco-East Bay, 1411 E 31st St (QIC 22134), Oakland, CA 94602 (E-mail: alden.harken68@gmail.com). J Thorac Cardiovasc Surg 2019;157:257-8

$0022-5223 / \$ 36.00$

Copyright (C) 2018 by The American Association for Thoracic Surgery

https://doi.org/10.1016/j.jtcvs.2018.08.005

As we get older, everything sags. When capable surgical electrophysiologists began measuring the origin of the sinus beat, we first learned that the textbook is correct that the "sinoatrial node" resides at the junction of the superior vena cava and right atrium-in a 21-year-old triathlete. But, as we age, the electrical origin of the P-wave drifts down toward the lateral wall of the right atrium.

A lot of people don't know this, but when Jim Cox and Jack Boineau began psychologically interrogating atrial periodicity, they became more interested in how the atrium "feels" than concerned about the $20 \%$ of Americans aged more than 70 years who have atrial fibrillation. So, Jimmy and Jack (understandably preprogrammed by Isaac Newton) presupposed that-like your jowls - the sinoatrial node is dragged south by gravity. And, if the rebels in the South can incite and control atrial conduction activity, why not all of the sleepy cardiomyocytes?

The breakthrough occurred when Jim and Jack recognized that atrial myocytes can "use Facebook" and could instantly talk to each other. These little cells, with age, began encouraging each other to join the fun and dance in circles. Then 2-seemingly simple-but profound observations surfaced: First, that all individual atrial myocytes can begin a line dance themselves, and second, that atrial fibrillation is not thousands of individual cells firing chaotically and independently. When a single Cesar Chavez or Martin Luther King grabs the hearts and souls of the atrial citizenry, the result is an organized reentrant dysrhythmia.

The accompanying article ${ }^{2}$ describes placing a Medtronic (Minneapolis, Minn) 252 body surface electrode vest on 10 patients with chronic atrial fibrillation before surgery. The goal was to delineate the anatomic distribution of reentrant and focal drivers of atrial dysrhythmias. The strengths and weaknesses of the study are the same. One patient presented with isolated coronary artery disease and therefore presumably had normal atrial pressures and diameter; a second patient had aortic stenosis and an ascending aneurysm; and 8 patients were surgically treated for mitral and tricuspid valvular disease. It is easy to assume that these patients were really very different. It is equally intuitively comfortable to conclude that these patients represent the

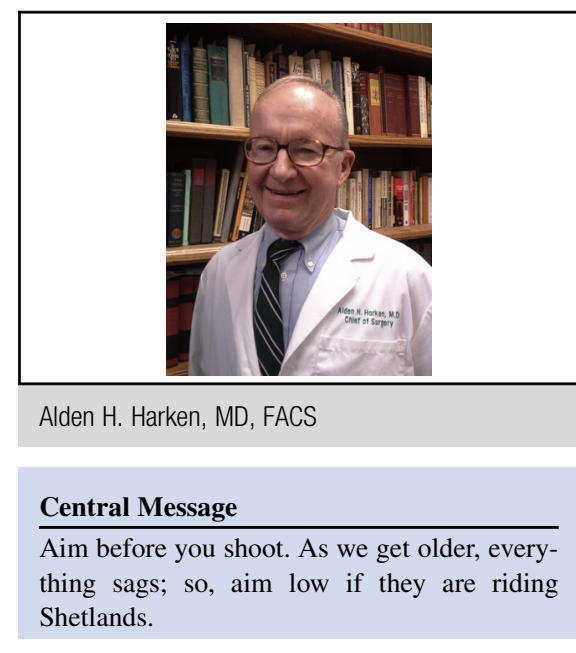

See Article page 248 .

whole spectrum of atrial hypertension and atrial stretch that predisposes to dysrhythmias.

Surgeons have long assumed that all cardiac dysrhythmias are automatic, reentrant, or a combination of both. Significantly, 289 of the 304 atrial fibrillatory rhythms characterized were reentrant and only 15 were focal/automatic. For a reentrant rhythm to sustain itself, an impulse must travel sufficiently slowly along one anatomic pathway that its origin has time to repolarize before that impulse returns - not too fast, and not too slow. The therapeutic advantage is weighted in favor of the surgeon. We just need to interrupt, or "screw up," the circuit anywhere along the path or alter the impulse velocity a tiny bit to disrupt the meticulous timing of a successful reentrant circuit. The complete Cox-maze procedure ${ }^{3}$ was uniquely designed to accomplish these circuit interruptions.

A formal Cox-maze IV in a deep-chested man with a small left atrium can be a struggle, so there has been recent significant enthusiasm to focus and restrict this intervention to the pulmonary vein region as the dominant culprit provoking atrial rhythm problems. ${ }^{4}$ The accompanying article $^{2}$ did identify a majority of culprit circuits in the region of the pulmonary veins, but different dysrhythmia-inciting regions in the right atria were also mapped in all 10 patients. Therefore, it is not surprising that patients undergoing a complete Coxmaze procedure enjoy better results than they do from any modifications. ${ }^{4}$ 


\section{References}

1. Boineau JP, Canavan TE, Schuessler RB, Cain ME, Corr PB, Cox JL. Demonstration of a widely distributed atrial pacemaker complex in the human heart. Circulation. 1988;77:1221-37.

2. Ehrlich MP, Laufer G, Coti I, Peter M, Andreas M, Stix G, et al. Noninvasive mapping before surgical ablation for persistent, long-standing atrial fibrillation. $J$ Thorac Cardiovasc Surg. 2019;157:248-56.
3. Cox JL, Schuessler RB, D’Agostino HJ Jr, Stone CM, Chang BC, Cain ME, et al The surgical treatment of atrial fibrillation. III. Development of a definitive surgical procedure. J Thorac Cardiovasc Surg. 1991;101:569-83.

4. Blackstone EH, Chang HL, Rajeswaran J, Parides MK, Ishwaran H, Li L, et al. Biatrial maze procedure versus pulmonary vein isolation for atrial fibrillation during mitral valve surgery: new analytical approaches and end points. $J$ Thorac Cardiovasc Surg. 2019;157:234-43.e9. 